\title{
Differential diagnosis of inflammatory myopathies, Becker muscular dystrophy (BMD) in a 10-year-old boy
}

\section{ABSTRACT}

The article presents the case of a 10-year-old boy referred for rheumatic diagnosis with suspected inflammation of the muscles without the presence of skin lesions in which Becker muscular dystrophy (BMD) was diagnosed.

In cases of isolated myopathy without skin lesions, it is necessary to exclude the neurogenic origin of muscle damage, muscular dystrophies and myasthenic disorders, additionally, viral, bacterial, parasitic infectious myopathy should be considered as a result of hormonal disturbances, drug poisoning and metabolic and electrolyte disorders.

Becker muscular dystrophy is a genetically conditioned disease that causes progressive and ir- reversible muscular atrophy, and is inherited in a recessive manner in gender-related intercourse. The incidence is around 1.5-6/100,000 births of boys. Becker dystrophy is a milder form of the Duchenne dystrophy type (DMD). The first symptoms occur at the age of 6-12 years. They include duck feet, problems with running and climbing stairs. The disease is progressive, initially affects the skeletal muscles, then also the myocardium leading to cardiomyopathy. Loss of ability to move independently occurs later, only after the age of 16 . The average survival period is 45 years.

Forum Reumatol. 2019, tom 5, nr 1: 43-46

Key words: myositis; muscular dystrophy; molecular diagnostics

\section{CASE REPORT}

A 10-year-old patient with possible myositis was admitted to the neurology ward. The patient, with no medical and family history, reported upper and lower extremity myalgias (arms, forearms and calves) and lower tolerance for physical activity. No fevers, weigh loss, cutaneous lesions or arthritis symptoms were observed in the patient. The boy did not suffer from any infections at the time. Outpatient tests showed only elevated levels of creatinine kinase (12 $493 \mathrm{U} / \mathrm{L}$ with a normal level of $30-170 \mathrm{U} / \mathrm{L})$.

The boy was born timely and naturally with gravida 1 para 1 , birth weight of $2,450 \mathrm{~g}$, Apgar 10, normal periparturient period. Normal psychosomatic development; the patient learned to sit at the age of 6-7 months, and to walk at the age of 12-13 months. In 2009, and the age of 3, he was hospitalised in Rabka due to possible tuberculosis (positive tuberculin reaction, contact with a person from the child's closest environment who suffered from tuberculosis), chemoprevention (Isoniazid) was applied. The boy was vaccinated according to the vaccination schedule.

At the time of admission to hospital, no deviations from the normal state were found in physical and neurological examination. Strength and muscle tension was normal, only symmetric hypertrophies of leg muscles were marked. The assessment of muscle strength in the CMAS scale was 51/53 points. Basic lab tests were normal with low inflammatory markers, the level of transminase was twice the
Address for correspondence: dr hab. n med. Zbigniew Żuber, prof. nadzw.

II Clinical Ward for Older Children with Neurology and Rheumatology subdivision at the St. Louis Regional Specialised Children's Hospital

ul. Strzelecka 2

31-503 Kraków tel.: +481261986 30 fax: + 48126198681 e-mail: zbyszekzuber@interia.pl 
upper limit, the level of creatinine kinase was tested 3 times during hospitalisation and oscillated between $670 \mathrm{U} / \mathrm{L}$ and 2,700 U/L (normal level up to $170 \mathrm{U} / \mathrm{L}$ ), the level of aldolase $17.8 \mathrm{U} / \mathrm{L}(\mathrm{N}$ to $7.6 \mathrm{U} / \mathrm{l})$. Serological examinations ruled out the following infections: EBV, hepatitis $\mathrm{B}$ and $\mathrm{C}, \mathrm{CMV}$, infections caused by streptococci, yersinosis, mycoplasma, borreliosis, and chlamydia trachomatis. Immunoassays showed no presence of anti-nuclear antibodies (ANA). Enzymatic tests for lysosomal storage disease (LSD) ruled out Pompe disease, Gaucher disease, Fabry disease and type I, II, III and VI mucopolysaccharidoses. Results of tests for metabolism errors, conducted using tandem mass spectrometry within amino acid and acylcarnitine profile, showed no presence of the aforementioned metabolic errors.

Imaging and functional examinations: RTG of the thorax, EKG, ultrasound of the abdominal cavity and echocardiographic examination were normal. In the examination of nerve conduction and right femoral nerve stimulation, action potential and latency value were normal. In the EMG examination from the quadriceps, a recording of increased polyphasia (recording from the quadriceps of the right thigh borderline normal, apart from the increased percentage of multiphase potentials). Bioelectric silence in resting recording, medium and singular parameters of action potentials, normal duration time and amplitude; medium-high, sometimes medium EMG. Magnetic resonance examination of focal areas (WB-MRI) was also conducted; no irregularities were found in the muscoskeletal system, soft tissue and internal organs. Biopsy of the quadriceps of the right thigh under light microscope showed non-characteristic myopathic changes of minor severity (irregularly distributed fibres of different diameter and size, including atrophied fibres. The nuclei of some fibres were located centrally. Some atrophied fibres are visible in the form of nuclear clumps, fasciculation maintained. Minor hypertrophy of adipose tissue and connective tissue is present in the perimysium. Within the interfascicular connective tissue and around a few fibres - small clumps of nucleated cells. Differentiation of fibres on the basis of metabolic types is maintained. Minor atrophy of type 2 fibres is visible.

Genetic examination using the MLPA method showed no deletion/duplication in the $D M D$ gene. On the other hand, a panel using the NGS method for dystrophy and myopathy showed hemizygous mutation c.9G > A (p. Trp3Ter9) in the DMD gene and hemizygous mutation c.304G > C (p. Asp102His) in the GYG1 gene.

On the basis of the overall clinical picture and the results of the tests, we can diagnose our patient with Becker muscle dystrophy, and as a carrier of myopathy with type 2 polyglucanose bodies. The final diagnosis was made within 22 months from the first hospitalisation, and within 3 years from the occurrence of the first symptoms. The molecular analysis of the $D M D$ gene was also conducted in the mother and the sister of our patient, in whom the carrier-status of c.9G > A was detected. The patient was placed under neurological, coronary, rheumatological and rehabilitation care.

\section{DISCUSSION}

Muscular pain is one of the most common symptoms reported by the patients of rheumatology outpatient clinics. While making the diagnosis, it is important to gather information on medical history concerning rheumatic diseases, family history, history concerning psychomotor development and presence of systemic symptoms. Differential diagnosis should consider sharp muscular pain, most often related to infections (viruses, parasites, bacteria), acute neurological syndromes, acute electrolyte disturbances. Sharp or chronic muscular pains may be related to inflammatory myopathies, myopathies occurring along with systemic diseases of connective tissue, endocrinological diseases, drug-induced myopathies or, like in the case of the described patient, dystrophic myopathies. In children, we also often encounter muscular pain related to joint hypermobility syndrome, spine strains and chronic fatigue syndrome that occurs less frequently.

Dystrophic myopathies are a large group of hereditary diseases that differ both in the inheritance model and the clinical image, in which degeneration and atrophy of skeletal muscles occur. For many years, dystrophy could only be diagnosed via clinical image, electromyographic examination (EMG) and muscle biopsy. Huge development of molecular genetics examinations, using immunocytochemical examinations and electronic microscope enabled the scientists to distinguish certain groups of dystrophia: dystrophinopathy, nucleopathy, limb-girdle dystrophy, facioscapulohumeral dystrophy [1-3]. 
Becker muscular dystrophy results from a mutation in the dystrophin gene which is present on the X locus Xp21.2-p21.1 chromosome. In patients suffering from the disease, deletion of one or more exons (60-70\%), duplications (5-10\%) and point mutations (25$35 \%$ ) are usually found.

The most common forms of dystrophy include dystrophinopathy - Duchenne/Becker muscular dystrophy (DMD/BMD). The cause of the dystropathies is mutation of dystrophin gene, located on the $\mathrm{X}$ locus p21.2-p21.1 chromosome, that is responsible for the lack or shortage of muscle tissue protein - dystrophin. The gene is build from 79 exons. Usually, deletion of 1 or more of the 79 exons (60-70\%), duplication (5-10\%) or point mutation (25-35\%), most often related to exon 3-7 or exon 44-45, is found. In genetic diagnostic, an examination using the MLPA (multiplex ligation dependent probe amplification) method is conducted in order to detect deletion or duplication within 79 exons for the dystrophin gene (4). In our patient, the examination with this method did not show deletion or duplication within the $D M D$ gene. Another examination includes detection of point mutations using the NGS panel. Molecular analysis of gene proved mutation that included exon 1 along with its surrounding intron fragments with presence of the c.9G > A variant (p. Trp3Tet9) of the $D M D$ gene in the hemizygous system. Molecular analysis of the GYG1 gene that included exon 3 of the GYG1 gene, using the Sanger method proved presence of c.304G $>\mathrm{C}$ variant (p.ASP102His) in GYG1 gene in the hemizygous system. The c. $9 \mathrm{G}>\mathrm{A}$ variant in the $D M D$ gene is of pathogenic nature and was described in patients with Duchenne and Becker muscular dystrophy. The c.304G > C variant in the GYG1 gene is also of pathogenic nature and was described in patients with myopathy and polyglucosan type 2 bodies. The results of the genetic tests in our patient allowed us to diagnose Becker muscular dystrophy and carrier-status of myopathy with polyglucosan bodies type 2 .

Duchenne muscular dystrophy (DMD) is a progressive disease; the first symptoms of it occur as early as at the beginning of the first decade of life, at the age between 2 and 4 . The core symptom is symmetrical affection of proximal muscles, beginning with the pelvic girdle and then the pectoral girdle. In some cases, hypertrophy or pseudohypertrophy of the calf muscles occurs. The first symptoms observable for the parents are clumsy, waddling gait, tendency to walk on toes, difficulties with climbing up the stairs and difficulties in rising from supine position (climbing up legs), difficulties in running. Excessive compensatory lumbar lordosis develops early. Deep reflexes gradually become weaker; at the earliest stages they concern patellar reflexes. Joint contractures and deformities of the spine occur. The disease is of progressive nature, and most patients can no longer walk independently around the age of 13. Deformity of the thorax and weakness of respiratory muscles are the causes of development of progressive respiratory failure. The average life span is 28 years. Respiratory failure $(40 \%)$ or heart failure secondary to cardiomyopathy $(10-40 \%)$ is the cause of death [3, $5,6]$.

Diagnostic biochemical tests assessing the activity of creatinine kinase in serum, muscle biopsy with myopathy features or abnormal dystrophin in immunocytochemical test, examinations that are useful for diagnosis are: EMG, ECG, echocardiogram, spirometry. Very high levels of CK before reaching the age of 5 (levels between 50-200 N) are characteristic; these levels later decrease by $20 \%$ per year. Conducting genetic testing is of paramount importance. Some authors believe that it may substitute conducting muscle biopsy.

In the case of DMD, there is no causative treatment. Prevention includes genetic guidance for families with history of dystrophinopathy. In children, steroid treatment (prednison $0.3-0.74 \mathrm{mg} / \mathrm{kg} /$ day) [2, 3]. It extends the period of independent walking by about 2-5 years, and it delays the occurrence of cardiomyopathy and scoliosis [2, 3]. The diet should be balanced and protein- and vitamin-rich. Modern rehabilitation methods along with orthopaedic surgeries allow the doctors to extend the ability to maintain standing position, prevent contractures in joints or spine scoliosis. Continuous cardiological and pulmonological supervision is important. Research using molecular methods - gene therapy - is conducted.

In BMD the course of the disease is less severe, the first symptoms occur later, at the age of 6-12, usually before reaching the age of 20 in $90 \%$ of patients clinical features of muscle weakness are found. The symptoms are similar to those listed while discussing the DMD form but they are significantly less severe. The course is slow; it affects the skel- 
etal muscles at the beginning, then also the cardiac muscle leading to cardiomyopathy. Loss of ability to move independently occurs only after reaching the age of 16 , and the patients usually remain able to move independently until the fourth decade of life or longer. Exertional calf muscle pain is one of the early symptoms present in around $30 \%$ of patients. The average life span is estimated to be around 40-45 years. Deaths due to respiratory failure or cardiovascular complications $[7,8]$.

Diagnostic examinations are the same as in the case of DMD. So far, no effective treatment has been discovered. In our patient, the diagnosis was made on the basis of molecular tests and the results of additional tests. In electromyography and muscle biopsy, features of myogenic disorders and presence of elevated $\mathrm{CPK}$, aldolase and transaminases in serum were found. Regrettably, no test for the lack or deficit of dystrophin in muscle biopsy was conducted.

\section{CONCLUSIONS}

When it comes to diagnosis, myopathies, which include progressive muscular dystrophies, are a challenge. Our patient's case is an example of diagnosis and clinical analysis that were conducted over many months before the final diagnosis of the disease was made. Diagnoses using molecular gene tests detecting deletions, duplications or dystrophin gene mutation are essential in this case. Mutations causing only partial deficit of dystrophin are related to a somewhat less severe phenotype, often leading to the development of BMD. The methods are not widely available yet. Precise determination of gene mutation may be, in the future, the condition for applying specific treatment methods, especially in the case of DMD. Due to the technical difficulties in point mutation detection that are still present, the gold standard for diagnosis of DMD and BMD should be to show a total lack of dystrophin in muscle specimen in the case of Duchenne dystrophy, or its deficiency in the case of Becker dystrophy [6].
References
1. Kissel JT, Mendell JR. Muscular dystrophy: historical overview and classification in the genetic era. Semin Neurol. 1999; 19(1): 5-7, doi: 10.1055/s-2008-1040821, indexed in Pubmed: 10711984.

2. Hausmanowi-Petrusewicz I. Choroby nerwowo-mięśniowe. Czelej, Lublin 2005: 167-178.

3. Szmidt-Sałkowska E. Dorobek M. Nowe poglądy na patogenezę dystrofii mięśniowych postępujących (DMP) Polski przegląd Neurologiczny. 2006; 2: 117-124.

4. Koening M, Beggs AH, Moyer M, etal. The molecular basis for Duchenne versus Becker Muscular Dystrophy: correlation of severity with type of deletion . Am.J.Hum.Genet. 1989; 45: 498-506.

5. Behrman RE, Kliegman RM, Nelson WE, Vaughan VC. Podręcznik pediatrii . PWN, Warszawa 1996.
6. Passamano I, Taglia A, Palladino A, et al. Improvement of survival in Duchenne muscular dystrophy: retrospective analysis of 835 patients. Acta Myologica. 2012; XXXI: 121-125.

7. Andrews JG, Wahl RA. Duchenne and Becker muscular dystrophy in adolescents: current perspectives. Adolesc Health Med Ther. 2018; 9: 53-63, doi: 10.2147/AHMT.S125739, indexed in Pubmed: 29588625 .

8. Beenakker EAC, Fock JM, Van Tol MJ, et al. Intermittent prednisone therapy in Duchenne muscular dystrophy: a randomized controlled trial. Arch Neurol. 2005; 62(1): 128-132, doi: 10.1001/archneur.62.1.128, indexed in Pubmed: 15642859. 


\section{Dorota Turowska-Heydel, Zbigniew Żuber}

II Oddział Kliniczny Dzieci Starszych z Pododdziałem Neurologii i Reumatologii Wojewódzkiego Specjalistycznego Szpitala Dziecięcego św. Ludwika w Krakowie

\section{$\mathbf{V M}$ \\ VIA MEDICA}

www.fr.viamedica.pl

\section{Diagnostyka różnicowa miopatii zapalnych, dystrofia mięśniowa Beckera (BMD) ॥ 10-letniego chłopca}

Artykuł jest tłumaczeniem pracy: Turowska-Heydel D., Żuber Z. Differential diagnosis of inflammatory myopathies, Becker muscular dystrophy (BMD) in a 10-years-old boy. Forum Reumatol. 2018; tom 5, nr 1: 43-46.

Należy cytować wersję pierwotną.

Piśmiennictwo znajduje się na stronie 46

\section{STRESZCZENIE}

W pracy przedstawiono przypadek 10-letniego chłopca skierowanego do diagnostyki reumatologicznej z podejrzeniem zapalenia mięśni bez obecności zmian skórnych, u którego rozpoznano dystrofię mięśniową Beckera (BMD).

W przypadkach izolowanych miopatii bez zmian skórnych konieczne jest wykluczenie neurogennego pochodzenia uszkodzenia mięśni, dystrofii mięśniowych oraz zaburzeń miastenicznych, ponadto należy rozważyć miopatie poinfekcyjne wirusowe, bakteryjne, pasożytnicze, miopatie w wyniku zaburzeń hormonalnych, zatrucia lekami oraz zaburzeń metabolicznych i elektrolitowych.

Dystrofia mięśniowa Beckera jest chorobą uwarunkowaną genetycznie, powodującą postępujący i nieodwracalny zanik mięśni, dziedziczoną w sposób recesywny w sprzężeniu z płcią. Częstość występowania wynosi około 1,5-6/100 000 urodzeń chłopców. Dystrofia Beckera jest łagodniejszą formą odmiany dystrofii Duchenne'a (DMD). Pierwsze objawy występują w wieku 6-12 lat. Obejmują one kaczkowaty chód, problemy z bieganiem i wchodzeniem po schodach. Choroba ma charakter postępujący, początkowo zajmuje mięśnie szkieletowe, potem również mięsień sercowy, prowadząc do kardiomiopatii. Utrata zdolności do samodzielnego poruszania występuje później, dopiero po 16. roku życia. Średni okres przeżycia wynosi 45 lat.

Forum Reumatol. 2019, tom 5, nr 1: 47-50

Słowa kluczowe: zapalenie mięśni; dystrofia mięśniowa; diagnostyka molekularna

\section{OPIS PRZYPADKU}

Pacjent w wieku 10 lat został przyjęty na oddział reumatologiczny $\mathrm{z}$ podejrzeniem zapalenia mięśni. Chory, z nieobciążonym wywiadem chorobowym i rodzinnym, zgłaszał występujące od około roku objawy bólów mięśniowych kończyn górnych i dolnych (ramion, przedramion oraz łydek) oraz pogorszenia tolerancji wysiłku fizycznego. U chłopca nie obserwowano stanów gorączkowych, ubytku masy ciała, zmian skórnych ani objawów zapalenia stawów. Chłopiec nie przechodził w tym okresie żadnych infekcji. W ambulatoryjnie wykonanych badaniach stwierdzano jedynie podwyższone wartości kinazy kreatyninowej (12 493 j./l przy normie 30 do 170 j./l).

Chłopiec urodzony z ciąży pierwszej, poród siłami natury o czasie, masa urodzeniowa 2450 g, Apgar 10, okres okołoporodowy prawidłowy. Rozwój psychosomatyczny prawidłowy, siadał w 6.-7. miesiącu życia, chodził w wieku 12.-13. miesięcy. W 2009 roku w wieku 3 lat hospitalizowany w Rabce z powodu podejrzenia gruźlicy (dodatni odczyn tuberkulinowy, kontakt z chorą na gruźlicę osobę z najbliższego otoczenia dziecka), zastosowano chemioprofilaktykę (izoniazyd) przez okres 6 miesięcy. Chłopiec został wyszczepiony zgodnie z kalendarzem szczepień.
Adres do korespondencji: dr hab. $n$ med. Zbigniew Żuber, prof. nadzw.

II Oddział Dzieci Starszych z Poddziałami Neurologii i Reumatologii

Szpitala Dziecięcego

św. Ludwika w Krakowie ul. Strzelecka 2 31-503 Kraków tel.: +481261986 30 faks: + 48126198681 e-mail: zbyszekzuber@interia.p 
W chwili przyjęcia na oddział w badaniu fizykalnym i neurologicznym nie stwierdzano odchyleń od stanu prawidłowego. Siła i napięcie mięśniowe były prawidłowe, jedynie zaznaczone były symetryczne przerosty mięśni podudzia. Ocena siły mięśniowej w skali CMAS wynosiła 51/53 punkty. Badania laboratoryjne podstawowe były prawidłowe z niskimi wskaźnikami stanu zapalnego, stężenie transaminaz przekraczał 2-krotnie normę, stężenie kinazy kreatyninowej wykonane 3-krotnie w trakcie hospitalizacji oscylował pomiędzy $670 \mathrm{j} . / 1$ a $2700 \mathrm{j} . / 1$ (norma do $170 \mathrm{j} . / \mathrm{l}$ ), stężenie aldolazy 17,8 j./l (norma do 7,6 j./l). Badaniami serologicznymi wykluczono infekcje: EBV, WZW typu B i C, CMV, infekcje wywołane przez paciorkowe, Yersinozę, Mykoplasme, Borelioze oraz Chlamydię trachomatis. W testach immunologicznych uzyskano brak obecności przeciwciał przeciwjądrowych (ANA). Wykonane badania enzymatyczne w kierunku lizosomalnych chorobach spichrzeniowych (LSD) wykluczyły chorobę Pompego, Gauchera, Fabre'ego oraz mukopolisacharydozy typu I, II, III i VI. Wyniki oznaczeń w kierunku wrodzonych wad metabolizmu wykonanych metodą tandemowej spektrometrii masowej w zakresie profilu aminokwasów oraz acylokarnityn nie wykazały obecności wyżej wymienionych wad metabolicznych.

Badania obrazowe i czynnościowe: RTG klatki piersiowej, EKG, USG jamy brzusznej, badanie echokardiograficzne były prawidłowe. W badaniu przewodnictwa nerwowego, stymulacji nerwu udowego prawego potencjał ruchowy i wartości latencji prawidłowe. W badaniu EMG z mięśnia czworogłowego uda prawego, zapis o zwiększonej polifazowości (zapis z mięśnia czworogłowego uda prawego na granicy normy poza wzmożonym odsetkiem potencjałów wielofazowych). W zapisie spoczynkowym cisza bioelektryczna, średnie i jednostkowe parametry potencjałów ruchowych, czas trwania i amplituda w granicach normy, zapis wysiłkowy pośredni bogaty, miejscami pośredni. Wykonano również badanie rezonansu magnetycznego ognisk zapalnych (MRI WB) nie stwierdzono nieprawidłowości sygnału w zakresie układu mięśniowo-szkieletowego, tkanek miękkich i narządów wewnętrznych. W biopsji z mięśnia czworogłowego uda lewego w badaniu w mikroskopie świetlnym stwierdzono niecharakterystyczne zmiany miopatyczne o niewielkim nasileniu (nieregularnie rozmieszczone włókna o różnej średnicy i kształcie, w tym włókna zanikłe. Część włókien zawierała centralnie położone jądra. Niektóre z zanikłych włókien widoczne są w formie nuclear clumps, układ pęczkowy zachowany. W perimysium obecny niewielki przerost tkanki łącznej i tłuszczowej. W obrębie tkanki łącznej zarówno między pęczkowej, jak i wokół kilku włókien niewielkie skupiska komórek jądrzastych. Różnicowanie włókien na typy metaboliczne było zachowane. Widoczny niewielki zanik włókien typu 2.

Badanie genetyczne metodą MLPA nie wykazało delecji/duplikacji w zakresie genu $D M D$. Natomiast panel metodą NGS w kierunku dystrofii i miopatii wykazał hemizygotyczną mutację c.9G > A (p. Trp3Ter9) w genie $D M D$ i hemizygotyczną mutację c.304G > C (p. Asp102His) w genie GYG1.

$\mathrm{Na}$ podstawie całościowego obrazu klinicznego, wyników badań rozpoznano u opisywanego pacjenta dystrofię mięśniową Beckera (BMD, Becker muscular dystrophy) i nosicielstwo miopatii z ciałkami poliglukozanowymi typu 2. Wiążącą diagnozę postawiono w przeciągu 22 miesięcy od daty pierwszej hospitalizacji, a w okresie około 3 lat od wystąpienia pierwszych objawów. Wykonano również analizę molekularną genu $D M D$ u matki i siostry pacjenta, stwierdzając nosicielstwo mutacji c.9G > A u ich obojga. Pacjenta objęto opieką neurologiczną, kardiologiczną, reumatologiczną oraz rehabilitacyjną.

\section{DYSKUSJA}

Dolegliwości bólowe mięśni to jeden z częstszych objawów zgłaszanych przez pacjentów poradni reumatologicznych. Przy ustaleniu diagnozy ważną rolę odgrywa prawidłowe przeprowadzenie wywiadu ukierunkowanego na choroby reumatyczne, na wywiad rodzinny, na wywiad dotyczący rozwoju psychoruchowego oraz obecność objawów ogólnoustrojowych. W diagnostyce różnicowej należy uwzględnić ostre bóle mięśniowe najczęściej związane ze schorzeniami infekcyjnymi (wirusy, pasożyty, bakterie), z ostrymi zespołami neurologicznymi, ostrymi zaburzeniami elektrolitowymi. Ostre lub przewlekłe bóle mięśniowe mogą wiązać się z miopatiami zapalnymi, miopatiami towarzyszącymi układowym chorobom tkanki łącznej, chorobom endokrynologicznym, miopatiami polekowymi, czy tak jak w przypadku opisywanego pacjenta, miopatiami dystroficznymi. U dzieci również często spotyka się ból mięśniowy związany zespołem nadmiernej ruchomości stawów, zespołami przeciążenia oraz rzadziej występującym zespołem przewlekłego zmęczenia. 
Miopatie dystroficzne to duża grupa dziedzicznych chorób mięśni, różniących się zarówno pod względem modelu dziedziczenia, jak i obrazu klinicznego, w których dochodzi do zwyrodnienia i zaniku mięśni poprzecznie prążkowanych. Przez wiele lat rozpoznanie dystrofii było jedynie możliwe poprzez obraz kliniczny, badanie elektromiograficzne (EMG) oraz biopsję mięśnia. Ogromny rozwój badań genetyki molekularnej, wykorzystywanie badań immunocytochemicznych i mikroskopu elektronicznego pozwoliło na wyodrębnienie określonych grup dystrofii: dystrofinopatii, nukleopatii, dystrofii obręczowo-kończynowych, dystrofii twarzowo-łopatkowo-ramiennej [1-3].

Dystrofia mięśniowa Beckera jest wynikiem mutacji w genie dystrofiny znajdujący się na chromosomie X locus Xp21.2-p21.1. U chorych zazwyczaj stwierdza się delecję jednego lub więcej eksonów (60-70\%), duplikacje (5$10 \%$ ) i mutacje punktowe (25-35\%).

Do najczęstszych postaci dystrofii zalicza się dystrofinopatię - dystrofię mięśniową Duchenne’a (DMD)/Beckera (BMD). U podłoża tych dystrofinopatii leży mutacja genu dystrofiny zlokalizowanego na chromosomie $\mathrm{X}$ locus p21.2-p21.1, odpowiedzialnego za brak lub ubytek białka komórki mięśniowej — dystrofiny. Gen zbudowany jest z 79 eksonów. Zazwyczaj stwierdza się delecję 1 lub więcej z 79 eksonów (60-70\%), duplikację (5-10\%), lub mutację punktową (25-35\%) dotyczącą najczęściej 3.-7. eksonu lub 44.-45. eksonu. $\mathrm{W}$ diagnostyce genetycznej wykonuje się badanie metodą MLPA (multiplex ligation dependent probe amplification) celem wykrycia delecji lub duplikacji w zakresie 79 eksonów dla genu dystrofiny [4]. U opisywanego pacjenta badanie tą metodą nie wykazało delecji ani duplikacji w obrębie genu $D M D$. Kolejne badanie to wykrycie punktowych mutacji przy użyciu panelu NGS. Analiza molekularna genu wykazała mutacje obejmującą ekson 1 wraz z otaczającymi fragmentami intronów z obecnością wariantu c.9G > A (p. Trp3Ter9) genu DMD w układzie hemizygotycznym. Analiza molekularna genu GYG1 obejmującego ekson 3 genu GYG1 metodą Sangera wykazała obecność wariantu c.304G > C (p.ASP102His) w genie GYG1 w układzie hemizygotycznym. Wariant c.9G > A w genie DMD ma charakter patogenny i został opisany u pacjentów z dystrofią mięśniową Duchenne'a i Beckera. Wariant c.304G > C w genie GYG1 ma również charakter patogenny i został opisany u pacjentów $\mathrm{z}$ miopatią z ciałkami poliglukozanowymi typu
2. Wyniki badań genetycznych u przestawionego pacjenta pozwoliły na rozpoznanie dystrofii mięśniowej Beckera i nosicielstwo miopatii z ciałkami poliglukozanowymi typu 2 .

Dystrofia mięśniowa postępująca Duchenne'a jest chorobą postępującą z pierwszymi objawami występującymi już w początku pierwszej dekady życia w wieku 2-4 lat. Osiowym objawem jest symetryczne zajęcie mięśni ksobnych, początkowo obręczy miednicy, a następnie barkowej. W części przypadków występuje przerost prawdziwy lub rzekomy mięśni łydek. Pierwsze objawy zauważalne przez rodziców to niezręczny, kaczkowaty chód, tendencja do chodzenia na palcach, trudności wchodzenia na schody i problemy ze wstawaniem z pozycji leżącej (wspinanie się po sobie), trudności z bieganiem. Wcześnie rozwija się kompensacyjna nadmierna lordoza lędźwiowa. Odruchy głębokie stopniowo słabną, najwcześniej dotyczą odruchów kolanowych. Pojawiają się przykurcze stawowe i zniekształcenia kręgosłupa. Choroba ma charakter postępujący, w wieku około 13 lat większość chorych nie jest w stanie samodzielnie chodzić. Zniekształcenie klatki piersiowej, osłabienie mięśni oddechowych jest przyczyną rozwoju postępującej niewydolności oddechowej. Średni okres przeżycia wynosi 28 lat. Niewydolność oddechowa (40\%) lub niewydolność serca wtórna do postępującej kardiomiopatii (10-40\%) jest przyczyną śmierci $[3,5,6]$.

Badania diagnostyczne i biochemiczne oceniające aktywność kinazy kreatynowej w surowicy, biopsja mięśnia z cechami miopatii lub nieprawidłowa dystrofina $\mathrm{w}$ badaniu immunocytochemicznym, badania pomocne w rozpoznaniu to: EMG, EKG, echo serca, spirometria. Charakterystyczne jest bardzo wysokie wartości CK przed 5. rokiem życia (norma 50-200) wartości te następnie obniżają się o około $20 \%$ na rok. Niezwykle istotne jest przeprowadzenie badania genetycznego. Niektórzy autorzy uważają, że może ono zastąpić wykonywanie biopsji mięśniowej.

W dystrofii DMD brak jest leczenia przyczynowego. Profilaktyka obejmuje poradnictwo genetyczne w rodzinach, u których wcześniej stwierdzono przypadki dystrofinopatii. U dzieci wskazana jest steroidoterapia (prednizon $0,3-0,75 \mathrm{mg} / \mathrm{kg} \mathrm{mc}$./dobę) [2, 3]. Wydłuża ona okres samodzielnego chodzenia o około 2-5 lat, opóźnia wystąpienie kardiomiopatii i skoliozy [2, 3]. Dieta powinna być zbilansowana bogato białkowa i bogato witaminowa. Nowoczesne metody rehabilitacji wraz z za- 
biegami ortopedycznymi pozwalają wydłużyć zdolność do utrzymania pozycji stojącej, zapobiegają powstawaniu przykurczów w stawach czy skrzywieniu kręgosłupa. Ważna jest stała kontrola kardiologiczna i pulmonologiczna. Prowadzone są badania z zastosowaniem metod molekularnych - terapii genowej.

W dystrofii BMD przebieg choroby jest łagodniejszy, pierwsze objawy występują później w wieku 6-12 lat zwykle przed ukończeniem 20. roku życia, u około $90 \%$ pacjentów stwierdza się klinicznie cechy osłabienia mięśni. Objawy są podobne do wymienionych przy postaci DMD, ale znacznie łagodniejsze. Przebieg jest powolny, początkowo zajmuje mięśnie szkieletowe, potem także mięsień sercowy, prowadząc do kardiomiopatii. Utrata zdolności do samodzielnego poruszania się występuje dopiero powyżej 16. roku życia, zwykle pacjenci zachowują zdolność do samodzielnego poruszana do czwartej dekady życia lub dłużej. Powysiłkowe bóle mięśni łydek są jednym z wczesnych objawów występujących u około $30 \%$ pacjentów. Średni okres przeżycia szacowany jest na około 40-45 lat. Zgon następuje z powodu niewydolności oddechowej lub powikłań kardiologicznych [7, 8].

Badania diagnostyczne są takie same, jak w przypadku dystrofii DMD. Jak dotąd nie ma skutecznej terapii leczniczej. Rozpoznanie u opisanego pacjenta postawiono na podstawie badań molekularnych oraz wyników badań do- datkowych. W elektromiografii i biopsji mięśnia stwierdzono cechy zaburzeń miogennych oraz obecność zwiększonej aktywności CPK, aldolazy, transaminaz w surowicy. Niestety nie wykonano badania braku lub deficytu dystrofiny w biopsji mięśniowej.

\section{PODSUMOWANIE}

Choroby pierwotnie mięśniowe, do których należą dystrofie mięśniowe postępujące, sprawiają duże trudności diagnostyczne. Przypadek opisanego pacjenta jest przykładem wielomiesięcznej diagnostyki i analizy klinicznej, które pozwoliły na ostateczne rozpoznanie choroby. Kluczowe znaczenie odgrywa diagnostyka za pomocą genetycznych badań molekularnych wykrywających delecje, duplikacje lub mutację genu dystrofiny. Mutacje powodujące jedynie częściowy niedobór dystrofiny wiążą się nieco z łagodniejszym fenotypem, prowadząc często do rozwoju BMD. Metody te nie sa jeszcze powszechnie dostępne. Dokładne określenie mutacji genowej może być w przyszłości warunkiem zastosowania swoistych metod leczenia, szczególnie w DMD. Ze względu na w dalszym ciągu trudności techniczne w wykrywaniu mutacji punktowych złotym standardem do rozpoznawania DMD i BMD powinno być wykazanie całkowitego braku dystrofiny w wycinku mięśnia w przypadku dystrofii Duchenne'a lub jej niedoboru w przypadku dystrofii Beckera [6]. 